\title{
DIMENSI KOMPETENSI MANAJERIAL KEPALA SEKOLAH SDN 006 DAN SDN 008 KECAMATAN KUALA KAMPAR, PELALAWAN
}

\author{
Hamzah \\ SMA Negeri 1 Kuala Kampar, Pelalawan \\ hamzahs328@yahoo.co.id
}

\begin{abstract}
Abstrak
Penelitian ini bertujuan untuk mendeskripsikan implementasi dimensi kompetensi manajerial dan periodisasi Kepala Sekolah SD Negeri 006 dan SD Negeri 008 Kecamatan Kuala Kampar, Pelalawan. Penelitian ini merupakan penelitian kualitatif dengan jenis penelitian studi kasus. Subjek penelitian adalah kepala sekolah, guru, Pengawas dan Kepala UPTD Pendidikan Kecamatan Kuala Kampar. Data penelitian dikumpulkan melalui wawancara dan dokumentasi serta dianalisis secara kualitatif menggunakan teknik analisis data model interaktif Miles \& Huberman. Hasil penelitian ini adalah sebagai berikut: (1) implementasi dimensi kompetensi manajerial kepala sekolah di kedua SD belum terlaksana dengan baik; (2) faktor-faktor kendala pelaksanaan dimensi kompetensi manajerial kepala sekolah di kedua SD yaitu: (a) jarak antara sekolah dengan kota menjadi penghambat program-program sekolah; (b) kurangnya sarana dan prasarana untuk menunjang proses belajar mengajar di sekolah; (c) Kepala sekolah telah bertugas lebih 25 tahun tanpa adanya periodisiasi jabatan sehingga motivasinya rendah; (d) Kepala sekolah belum memiliki kompetensi sesuai dengan Permendiknas; (e) kurang kerja sama antara kepala sekolah dengan bawahannya; (3) Faktor-faktor yang mempengaruhi periodisasi jabatan kepala sekolah: (a) permohonan dari tokoh masyarakat di lingkungan sekolah kepada Kepala UPTD Kecamatan Kuala Kampar karena kepala sekolah dianggap sebagai salah satu tokoh yang dibutuhkan oleh masyarakat; (b) ada kekhawatiran kepala sekolah baru tidak dapat beradaptasi dengan kondisi lingkungan masyarakat; (c) ada kekhawatiran timbulnya dampak sosial di masyarakat apabila kepala sekolah tetap diganti.
\end{abstract}

Kata kunci: kompetensi manajerial, kepala sekolah

\section{THE DIMENSIONS OF MANAGERIAL COMPETENCE OF THE HEADMASTER OF SDN 006 AND SDN 008 KUALA KAMPAR SUBDISTRICT, PELALAWAN}

\author{
Hamzah \\ SMA Negeri 1 Kuala Kampar, Pelalawan \\ hamzahs328@yahoo.co.id
}

\begin{abstract}
The purpose of this research is to describe the implementation of Managerial Competence and Periodization of The Headmasters of SD Negeri 006 and SD Negeri 008, Kecamatan Kuala Kampar, Pelalawan. It is a qualitative research with a case study. The subject of the research is the headmaster, teachers, Supervisor and the Head of UPTD of Kecamatan Kuala Kampar. The data were collected through interview, observation, and documentation which were also analyzed qualitatively using an interactive model data analysis technique by Miles $\mathcal{E}$ Huberman. The results of the research are as follows: (1) the implementation of managerial competence of the headmasters of both schools has not been implemented well yet suited to the indicator of managerial standard competence; (2) the factors inhibiting the implementation of managerial competence in both schools are as follows: (a) the location of the schools is far from the city which inhibit the school programs; (b) the lack of means and infrastructures to support the teaching and learning processes at schools; (c) the lack of motivation by the headmasters. The headmasters had been in charge for 25 years without any periodization of the position, (d) the headmasters do not have a standard competence of headmaster according to the government regulation; (e) the lack of coordination and cooperation between the headmasters and their subordinates; (3) the factors affecting the periodization of headmaster position: (a) the request from the public figure in the school environment to the Head of UPTD of Kecamatan Kuala Kampar, since the headmaster is one of the figures needed by the society; (b) there is a worry from UPTD that a new headmaster will not be able to adapt to the environment of the society; (c) There is a worry from UPTD for the social impact arises in the society if the headmaster is replaced.
\end{abstract}

Keywords: managerial competence, headmaster 


\section{Pendahuluan}

Keberhasilan suatu lembaga pendidikan sangat tergantung pada kepemimpinan kepala sekolah. Kepala sekolah sebagai pemimpin harus mampu membawa lembaganya mencapai tujuan yang telah ditetapkan. Kepemimpinan kepala sekolah merupakan salah satu faktor yang dapat mendorong diwujudkannya visi, misi, tujuan, dan sasaran sekolah melalui program-program yang dilaksanakan secara terencana dan bertahap. Perbedaan sekolah yang baik dengan sekolah yang buruk dilihat dari baik buruknya kinerja kepala sekolah, tidak ada sekolah yang baik tanpa dipimpin oleh kepala sekolah yang baik. Kepala sekolah memiliki peran penting dalam mengoordinasikan, menggerakkan, dan menyerasikan semua sumber daya pendidikan. Oleh karena itu, kepala sekolah dituntut mempunyai kompetensi yang mmadai agar mampu mengambil inisiatif untuk meningkatkan mutu sekolah.

Permendiknas Nomor 13 Tahun 2007, tentang Standar Kepala Sekolah/Madrasah (Depdiknas, 2007) menjelaskan bahwa kompetensi kepala sekolah terdiri atas lima dimensi yaitu: kepribadian, manajerial, kewirausahaan, supervisi, dan sosial. Selain itu, penataan sistem Periodisasi kepala sekolah perlu dilakukan sesuai dengan Permendiknas 28 Tahun 2010, tentang Penugasan Guru sebagai Kepala Sekolah/Madrasah (Depdiknas, 2010). Tujuan periodisasi selain memberikan penilaian dan bimbingan terhadap kepala sekolah, juga bertujuan untuk memberikan kesempatan terhadap guru lainnya yang memiliki kompetensi menjadi kepala sekolah.

Berdasarkan hasil prasurvei kepala sekolah SD Negeri 006 Tanjung Sum telah bertugas sebagai kepala sekolah selama lebih 25 tahun berdasarkan SK Bupati Pelalawan KPTS/853/PKS/2000/186. Begitu juga Kepala Sekolah SD Negeri 008 Sungai Solok telah bertugas selama lebih 25 tahun berdasarkan SK Bupati Pelalawan KPTS/853/PKS/2000/187. Selama lebih 25 tahun bertugas sebagai kepala sekolah tidak pernah dimutasi di sekolah lain. Selama masa kepemimpinannya secara umum tidak membawa perubahan yang signifikan bagi sekolah yang dipimpinnya. Bahkan semakin tertinggal dari sekolah-sekolah lain.

Fenomena lain yang dapat dilihat berdasarkan pengamatan dan wawancara dengan beberapa guru di SDN 006 dan SDN 008 adalah masih banyak guru-guru tidak memiliki perangkat pengajaran (Rencana Pelaksanaan Pembelajaran, Silabus, Program tahunan dan Program semester). Mereka tidak mampu membuat bahan ajar, masuk kedalam kelas hanya bermodal sebuah buku ajar. Sering terlambat masuk ke dalam kelas dan cepat keluar dari kelas yang berarti jam efektif di depan kelas tidak cukup. Kesalahan dalam perencanaan dan pelaksanaan sudah pasti akan diikuti dengan kesalahan pada penilaian dan analisis hasil belajar serta tindaklanjutnya. Seharusnya ini dapat ditindaklanjuti apabila terjalin komunikasi yang baik antara kepala sekolah dengan guru. Permasalahan lain yang dapat diidentifikasi adalah berkaitan dengan administrasi sekolah yang masih tidak teratur pengelolaanya. Penyusunan Rencana Anggaran Pendapatan Belanja Sekolah (RAPBS) belum terbuka. Guru dan anggota sekolah lainnya tidak dilibatkan dalam perencanaan anggaran. Selain itu komite sekolah juga tidak dilibatkan dalam penyususnan Rencana Anggaran Pendapatan Belanja Sekolah (RAPBS).

Melihat fenomena di SD Negeri 006 Tanjung Sum dan SD Negeri 008 Sungai Solok Kecamatan Kuala Kampar Kabupaten Pelalawan, peneliti tertarik untuk meneliti lebih jauh terkait dengan "Dimensi Kompetensi Manajerial Kepala Sekolah SD Negeri 006 Tanjung Sum dan SD Negeri 008 Sungai Solok Kecamatan Kuala Kampar Kabupaten Pelalawan Provinsi Riau"

Kepala sekolah menjadi kunci utama dan tokoh sentral untuk mewujudkan perbaikan kinerja manajemen sekolah dan peningkatan kualitas pendidikan di Indonesia. Hal ini seiring dengan diberikannya wewenang yang lebih besar kepada kepala sekolah untuk mengelola lembaga sekolahnya sendiri. Menurut Kompri (2015), kepala sekolah adalah orang yang memiliki ke- 
kuasaan serta pengaruh dalam menentukan kegiatan belajar mengajar di sekolah itu, kehidupan di sekolah diatur sedemikian rupa melalui kepemimpinan seorang kepala sekolah.

Menurut Zahid \& Gihar (2012, p. 42), the principal holds a very important position in the entire system of education and he is the principal means for the implementation of educational programmers. Seorang kepala sekolah memegang posisi yang sangat penting dalam seluruh sistem pendidikan dan kepala sekolah merupakan pelaksana program pendidikan yang disepakati bersama. kepala sekolah dapat diartikan sebagai seorang pemimpin yang mempunyai usaha dalam pendidikan dan pengajaran yang banyak dibebani dengan kewajiban-kewajiban yang beraneka ragam untuk mencapai tujuan yang diinginkan. Brookover \& Edmonds (Sergiovanni, 2006) mengemukakan bahwa sekolah yang efektif ditandai dengan tingginya komitmen antarstaf terhadap tujuan sekolah, kejelasan terhadap misi sekolah, dan keaktifan dalam upaya pencapaiannya. Penelitian juga menemukan bahwa kepala sekolah secara konsisten merupakan faktor penentu keefektifan sekolah

Kepala sekolah adalah jabatan dalam lembaga pendidikan yang menduduki pucuk pimpinan di lembaga yang dipimpinnya. Oleh karena itu, sama halnya dengan jabatan-jabatan yang lainnya, kepala sekolah harus memiliki beberapa standar kompetensi yang berkaitan dengan jabatannya. Menurut Wahyudi (2012, pp. 28-29) kompetensi kepala sekolah adalah Pengetahuan, keterampilan dan nilai-nilai dasar yang direfleksikan kepala sekolah dalam kebiasaan berfikir dan bertindak secara konsisten yang memungkinkannya menjadi kompeten atau berkemampuan dalam mengambil keputusan tentang penyediaan, pemanfaatan dan peningkatan potensi sumberdaya untuk meningkatkan kualitas pendidikan di sekolah.

Permendiknas Nomor 13 Tahun 2007, tentang Standar Kepala Sekolah/Madrasah (Depdiknas, 2007), kompetensi kepala sekolah terdiri atas lima dimensi seperti disebutkan sebelumnya. Selain itu, Yukl (2009, p. 34) menyatakan, kewajiban dan tanggung jawab tersebut adalah: (1) supervisi, (2) merencana dan mengorganisasi, (3) pembuatan keputusan, (4) memantau indikator, (5) pengendalian, (6) memberi penjelasan, (7) mengkoordinasi, (8) konsultasi, (9) mengadministrasikan.

Menurut Robbins \& Judge (2013, p. 39) "Managers get things done through other people. They make decisions, allocate resources, and direct the activities of others to attain goals. Managers do their work in an organization, which is a consciously coordinated social unit, composed of two or more people, that functions on a relatively continuous basis to achieve a common goal or set of goals." Manajer menyelesaikan sesuatu melalui orang lain. Mereka membuat keputusan, mengalokasikan sumber daya, dan mengarahkan kegiatan orang lain untuk mencapai tujuan. Manajer melakukan pekerjaan mereka dalam suatu organisasi, yang merupakan unit sosial sadar terkoordinasi, terdiri atas dua orang atau lebih, yang berfungsi secara relatif terus menerus untuk mencapai tujuan bersama atau serangkaian tujuan. Selain itu, Menurut Armstrong (2009, p. 15) "Managers are there to get results by ensuring that their function, unit or department operates effectively. They manage people and their other resources finance, facilities, knowledge, information, time and themselves." Manajer ada untuk mendapatkan hasil dengan memastikan bahwa fungsi mereka, Unit atau departemen beroperasi secara efektif. Mereka mengelola sumber daya, fasilitas, pengetahuan, informasi, waktu dan diri mereka sendiri. Mereka bertanggung jawab untuk mencapai tujuan, yang telah diberi atas mereka.

Danim \& Suparno (2009, p. 7) menjelaskan, sebagai manajer kepala sekolah harus mampu bekerja dengan dan melalui wakil-wakilnya, atau yang populer disebut sebagai "a good manager is doing the things by other people." Dengan kata lain seorang manajer tidak bisa bekerja sendirian tanpa ada dukungan dari pihak lain didalam suatu organisasi tersebut. Kepala sekolah dituntut memiliki kemampuan sebagai 
manajer dalam suatu organisasi sekolah. Menurut Ndidi, Obigeli, \& Peace (2013, p. 173), "Managing educational systems demand that school principals should possess adequate manajerial skills." Mengelola sistem pendidikan menuntut kepala sekolah yang memiliki kemampuan manajerial yang memadai. Menurut Pidarta (2011, p. 2), manajer mempunyai empat fungsi serta dilengkapi dengan keterampilan yaitu (1) perencanaan, yaitu merancang untuk mengatasi masalah tersebut, (2) pengorganisasian, yaitu mengorganisasi orang dan kelengkapan lainnya agar perencanaan tersebut dapat berjalan, (3) pengerakan, ialah menggerakkan dan memotivasi para personalia agar bekerja dengan giat dan atosias, (4) pengendalian, ialah mengendalikan proses kerja dan hasil kerja agar tidak menyimpang dari rencana semula dan kalau menyimpang agar segera dapat diperbaiki. Mintzberg (Toha, 2012, pp. 12-17) mengemukakan peranan utama seorang manajer yang terbagi dalam 3 peranan utama, yaitu (1) peranan hubugan antarpribadi. (2) peranan hubungan dengan informasi. (3) peranan pembuat keputusan. Menurut Bennis $(2009$, p. 42) perbedaan peran antara manajer dan pemimpin disajikan pada Tabel 1.

\section{Tabel 1. Perbedaan Peran Antara Manajer} dan Pemimpin

\begin{tabular}{ll}
\hline \multicolumn{1}{c}{ Manajer } & \multicolumn{1}{c}{ Pemimpin } \\
\hline Mengelola & Menginovasi \\
Tiruan & Orisinal \\
Mempertahankan & Mengembangkan \\
Berfokus pada sistem & Fokus kepada orang \\
Bergantung kepada & Membangkitkan \\
pengawasan & kepercayaan \\
Melihat jangka pendek & Melihat perspektif \\
Bertanya kapan dan & jangka panjang \\
bagaimana & Bertanya apa dan \\
Melihat hasil pokok & mengapa \\
Meniru & Menatap masa depan \\
Menerima status quo & Melahirkan \\
Prajurit yang bai & Menantangnya \\
Melakukan hal-hal & Dirinya sendiri \\
dengan & Melakukan hal-hal \\
& yang \\
\hline
\end{tabular}

Kementerian Pendidikan Nasional telah menerbitkan regulasi baru yang ber- kaitan dengan Kepala Sekolah/Madrasah yaitu Peraturan Menteri Pendidikan Nasional (Permendiknas) Nomor 28 Tahun 2010 tentang Penugasan Guru sebagai Kepala Sekolah/Madrasah. Permendiknas No 28 tahun 2010 tidak hanya mengatur persyaratan bagi seorang guru untuk diberi tugas tambahan sebagai kepala sekolah/madrasah, tetapi juga mengatur penyiapan calon kepala sekolah/madrasah (meliputi rekrutmen serta pendidikan dan pelatihan calon kepala sekolah/madrasah), proses pengangkatan kepala sekolah, masa tugas, pengembangan keprofesian, penilaian kinerja, mutasi dan pemberhentian kepala sekolah/madrasah.

Periodisasi kepala sekolah telah diatur dalam Permendiknas No 28 Tahun 2010 Bab V tentang Masa Tugas kepala sekolah Pasal 10, yaitu: (1) Kepala sekolah/madrasah diberi 1 (satu) kali masa tugas selama 4 (empat) tahun. (2) Masa tugas kepala sekolah/madrasah sebagaimana dimaksud pada ayat (1) dapat diperpanjang untuk 1 (satu) kali masa tugas apabila memiliki prestasi kerja minimal baik berdasarkan penilaian kinerja. (3) Guru yang melaksanakan tugas tambahan sebagai kepala sekolah/madrasah 2 (dua) kali masa tugas berturut-turut, dapat ditugaskan kembali menjadi kepala sekolah/madrasah di sekolah/madrasah lain yang memiliki nilai akreditasi lebih rendah dari sekolah/madrasah sebelumnya, apabila: a. telah melewati tenggang waktu sekurang-kurangnya 1 (satu) kali masa tugas; atau b. memiliki prestasi yang istimewa. (4) Prestasi yang istimewa sebagaimana dimaksud pada ayat (3) huruf $b$ adalah memiliki nilai kinerja amat baik dan berprestasi di tingkat kabupaten/kota/provinsi/nasional. (5) Kepala sekolah/madrasah yang masa tugasnya berakhir, tetap melaksanakan tugas sebagai guru sesuai dengan jenjang jabatannya dan berkewajiban melaksanakan proses pembelajaran atau bimbingan dan konseling sesuai dengan ketentuan.

Berdasarkan Permendiknas Nomor 28 Tahun 2010, Guru dapat diberikan tugas tambahan sebagai kepala sekolah/madrasah untuk memimpin dan mengelola se- 
kolah/madrasah Masa Tugas ataupun Masa Jabatan Kepala sekolah/madrasah diberi 1 (satu) kali masa tugas selama 4 (empat) tahun. Masa tugas kepala sekolah/madrasah dapat diperpanjang untuk 1 (satu) kali masa tugas apabila memiliki prestasi kerja minimal baik berdasarkan penilaian kinerja. Guru yang melaksanakan tugas tambahan sebagai kepala sekolah/madrasah 2 (dua) kali masa tugas berturut-turut, dapat ditugaskan kembali menjadi kepala sekolah/madrasah di sekolah/madrasah lain yang memiliki nilai akreditasi lebih rendah dari sekolah/madrasah sebelumnya, apabila telah melewati tenggang wak-tu sekurang-kurangnya 1 (satu) kali masa tugas; atau memiliki prestasi yang istimewa.

Sekolah efektif membutuhkan kepemimpinan kepala sekolah untuk mengarahkan dan memotivasi warga sekolah dan semua pihak yang terlibat seperti guru, staf, siswa, orang tua murid, masyarakat agar bersedia bekerja sama untuk mencapai tujuan sekolah yang diharapkan. Kepemimpinan kepala sekolah yang efektif perlu menerapkan strategi kepemimpinan yang tepat yang sesuai dengan konteks yang dihadapi, terutama karakterstik dan kemampuan pengikutnya. Sergiovanni, (2006, p. 159) mengatakan "not every situation a principal requires the same leadership strategy. The principal of a highly competent and well-motivated faculty will have to proceed one way and the principal of a developing and uncommitted faculty will have to proceed another way. principals must practice leadership in light of the context they fac." Terdapat empat strategi kepemimpinan kepala sekolah yang masing-masing dipertimbangkan efektif untuk konteks tertentu:

Bartering yaitu kepala sekolah dan guru sepakat bahwa pemimpin memberikan kepada yang dipimpin apa yang diinginkan sebagai ganti atau tukar atas apa yang diinginkan pemimpin. Gaya kepemimpinan ini menekankan pada 'trading' keinginan dan kebutuhan kerja sama dan kepatuhan. Pendekatan ini akan menciptakan hubungan berdasarkan 'barter' pemenuhan keinginan dan kebutuhan pimpinan dan bawahan. Pendekatan ini paling tepat digunakan ketika kepala sekolah dan guru tidak berbagi tujuan dan kepentingan bersama atau dengan kata lain ketika kebutuhan dan kepentingan kepala sekola dan guru berbeda.

Building, yaitu kepala sekolah menciptakan iklim dan dukungan interpersonal yang baik untuk meningkatkan kesempatan staf memenuhi kebutuhan prestasi, tanggung jawab, kompetensi, dan penghargaan diri. Gaya kepemimpinan ini hanya sedikit menekankan pada trading, dan lebih pada penciptaan kondisi yang memungkinan guru-guru terpenuhi kebutuhan psikologisnya. Jika tingkat minimal upaya bersama telah dicapai, pendekatan ini menyarankan untuk merubah hadiah dari yang bersifat ekstrinsik ke intrinsik.

Binding, kepala sekolah dan guru bersama-sama mengembangkan nilai bersama tentang hubungan dan ikatan yang samasama mereka inginkan sehingga bersamasama mereka bisa menjadi komunitas pembelajar dan pemimpin.

Bonding, kepala sekolah dan personel bersatu dalam satu hubungan dan komitmen yang menjadikan pengembangan sekolah melembaga dalam kehidupan sehari-hari sekolah. Gaya kepemimpinan ini menekankan pada hubungan saling peduli dan tergantung yang dihasilkan dari pelaksanaan kewajiban dan komitmen bersama. Dalam gaya ini, kepemimpinan dan pengembangan akan dapat terus berjalan. Orang-orang menjadi sebuah komunitas satu pikiran, hati dan praktek. Gaya dan strategi kepemimpinan ini lebih menekankan moral sebagai sumber kekuasaan.

Kunci keberhasilan suatu sekolah pada hakikatnya terletak pada efesiensi dan efektivitas penampilan seorang kepala sekolah. Keberhasilan sekolah adalah keberhasilan kepala sekolah. Secara filosofis, perilaku manusia terbentuk oleh interaksi antarmanusia, iklim organisasi, dan sistem yang dianut. Ketiga interaksi tersebut, baik secara sendiri-sendiri maupun secara bersama-sama saling berinteraksi dengan lingkungan eksternalnya seperti yang disampaikan oleh Usman (2013, p. 18) pada Gambar 1. 


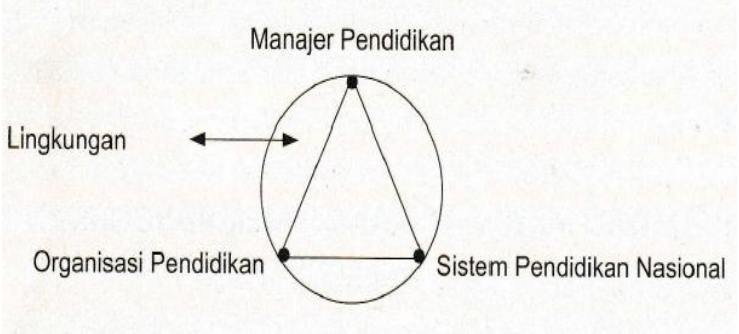

Gambar 1. Faktor-faktor yang Mempengaruhi Perilaku Manajer

Manusia sebagai manajer di manapun tidak terlepas dari wadah untuk melakukan kegiatan atau disebut Organisasi. organisasi dapat berupa lembaga pendidikan formal, nonformal maupun informal. Organisasi tidak ada tanpa ada manusia. Manusia dalam berorganisasi tidak luput dari sistem yang dibuatnya sendiri. Sistem sangat diperlukan agar cara berpikir, berperasaan, dan bertindak setiap anggota organisasi tidak terkotak-kotak melainkan menyeluruh. Selain itu, faktor-faktor lain yang menjadi kendala dalam menjalankan dimensi-dimensi kompetensi manajerial adalah sebagai berikut:

Tantangan terbesar dalam organisasi adalah mengidentifikasi sumber daya manusia secara individu yang cocok dengan persyaratan jabatan yang akan dipangkunya, atau individu yang berpotensi untuk di kembangkan agar cocok, memenuhi persyaratan yang diperlukan untuk jabatan tersebut. Di dalam Permendiknas Nomor 28 Tahun 2010 Pasal 5 Ayat 1 bahwa tahap pengangkatan kepala sekolah dilakukan melalui seleksi baik itu administrasi yang wajib dipenuhi oleh seorang calon kepala sekolah maupun akademik yang menunjang kemampuan manajerial kepala sekolah tersebut (Depdiknas, 2010). Kendalanya adalah para calon kepala sekolah yang diangkat oleh pemerintah daerah tidak memiliki kompetensi yang telah diatur dalam peraturan pemerintah tentang standar kompetensi kepala sekolah.

Wahjosumidjo, (1999, p. 351) mendefinisikan, "Seleksi adalah suatu proses pengambilan keputusan terhadap individu yang dipilih karena kebaikan yang dimilikinya dari pada yang lain, untuk mengisi suatu jabatan yang didasarkan pada karak- ter atau sifat-sifat baik, sesuai dengan persyaratan jabatan yang diinginkan." Dari definisi tersebut dapat diketahui bahwa tujuan seleksi adalah untuk mengisi kekosongan jabatan yang ada dengan orang yang memenuhi kualifikasi yang diharapkan.

Pendidikan dan pelatihan merupakan bentuk pengembangan sumber daya manusia yang sangat strategis. Karena dalam program pendidikan dan pelatihan selalu berkaitan dengan masalah nilai, norma dan perilaku individu dan kelompok. Permendiknas Nomor 28 Tahun 2010 Pasal 7 Ayat 1 dijelaskan bahwa: Pendidikan dan pelatihan calon kepala sekolah/madrasah merupakan kegiatan pemberian pengalaman pembelajaran teoretik maupun praktik yang bertujuan untuk menumbuhkembangkan pengetahuan, sikap dan keterampilan pada dimensi-dimensi kompetensi kepribadian, manajerial, kewirausahaan, supervisi, dan sosial.

Dalam peningkatan kualitas kepemimpinan kepala sekolah, ada beberapa tahap yang harus dilewati dari penyeleksian dan pengangkatan kepala sekolah, program pendidikan dan pelatihan serta evaluasi hasil kinerja yang dilakukan oleh pemerintah.

Berdasarkan permendiknas Nomor 28 Tahun 2010 pasal 12 ayat 1 menyebutkan bahwa penilaian kinerja kepala sekolah dilakukan secara berkala setiap tahun dan secara komulatif setiap 4 tahun. Lebih lanjut ayat 3 menyatakan bahwa penilaian kinerja 4 tahun dilaksanakan oleh atasan langsung dengan mempertimbangkan penilaian kinerja oleh tim penilai yang terdiri atas pengawas sekolah, pendidik, tenaga kependidikan dan komite sekolah dimana yang bersangkutan bertugas (Depdiknas, 2010).

Selain ketiga faktor tersebut menurut Busher (2006, p. 141) menjelaskan pentingnya iklim kerja yang kondusif dalam sebuah lembaga untuk mencapai tujuan bursama. "An important element in middle leaders' success in running departments is their ability to help colleagues develop their capacities as teachers and leaders. To do this, leaders need to understand colleagues' personal and work- 
related needs and interests and help them to understand the culture of their particular school, to engage with the sub-culture of the department and to appreciate the complexity of students' small cultures" Sebuah elemen penting dalam keberhasilan pemimpin tengah dalam menjalankan departemen adalah kemampuan mereka untuk membantu rekan-rekan mengembangkan kapasitas mereka sebagai guru dan pemimpin. para pemimpin perlu memahami kebutuhan dan kepentingan pribadi dan pekerjaan yang berhubungan dan membantu mereka untuk memahami budaya sekolah

\section{Metode Peneitian}

Metode yang digunakan dalam penelitian ini adalah kualitatif. Sedangkan jenis penelitian ini secara spesifik lebih diarahkan pada penggunaan studi kasus. Peneliti memilih penelitian studi kasus karena dalam penelitian ini peneliti ingin berusaha mengungkapkan secara mendalam tentang fakta dibalik fenomena dimensi kompetensi manajerial kepala sekolah dan periodisasi jabatan kepala sekolah di SD Negeri 006 dan SD Negeri 008 Kecamatan Kuala kampar dan SD Negeri 008 Sungai Solok di Kecamatan Kuala Kampar Kabupaten Pelalawan.

Tempat penelitian ini dilaksanakan di SD Negeri 006 dan SD Negeri 008 Kecamatan Kuala kampar yang beralamat di jalan Raya Tanjung Sum RT/RW 04/06 Kelurahan Tanjung Sum dan di SD Negeri 008 Sungai Solok yang beralamat dijalan Batu Aji RT/RW 02/03 Sungai Solok Kecamatan Kuala Kampar Kabupaten Pelalawan Provinsi Riau. Alasan pemilihan lokasi penelitian didasarkan atas pertimbangan bahwa SD Negeri 006 dan SD Negeri 008 Kecamatan Kuala kampar dan SD Negeri 008 Sungai Solok merupakan sekolah yang dipimpin oleh kepala sekolah yang telah bertugas selama lebih dari 25 tahun tidak pernah dimutasi dan perkembangan sekolah tersebut juga cendrung lambat dan tertinggal dari sekolah lain. Waktu pada penelitian ini dilaksanakan dari bulan Desember 2015 s.d. Maret 2016. Sedangkan Kegiatan penelitian ini dimulai sejak disah- kannya proposal penelitian serta surat ijin penelitian, yaitu 11 November sampai dengan 26 Desember 2015.

Adapun sumber data dalam penelitian ini adalah kepala sekolah SD Negeri 006 dan SD Negeri 008 Kecamatan Kuala kampar dan SD Negeri 008 Sungai Solok sebagai key informan. Kepala sekolah sebagai pemimpin lembaga diharapkan mengetahui informasi tentang kompetensi manajerial yang harus dilaksanakan di sekolah. Guru dipilih sebagai informan karena terlibat langsung dalam pelaksanaan keputusan kepala sekolah dalam dimensi dimensi kompetensi manajerial sehingga mengetahui ketercapaian dalam pelaksanaan di sekolah. Pengawas Sekolah Kecamatan Kuala Kampar dan KA.UPTD Pendidikan Kecamatan Kuala Kampar. Di pilih sebagai informan karena terlibat langsung dalam pengawasan dan kebijakan pendidikan sehingga diharapkan dapat memberikan informasi berkaitan dengan Periodisasi kepala sekolah.

Teknik pengumpulan data merupakan langkah yang amat penting dalam penelitian, karena data yang terkumpul akan dijadikan sebagai bahan analisis penelitian. Teknik pengumpulan data erat kaitannya dengan masalah penelitian yang akan dipecahkan. Teknik pengumpulan data yang digunakan dalam penelitian ini adalah Wawancara dan Studi Dokumentasi.

Instrumen pengumpulan data dalam penelitian kualitatif adalah peneliti itu sendiri yang mengunakaan instrumen pendukung berupa pedoman wawancara dan pedoman dokumentasi. Pedoman wawancara berisi tentang sejumlah pertanyaan-pertanyaan yang ditanyakan kepada informan untuk mengungkap informasi secara mendalam tentang kompetensi kepala sekolah.

Suatu penelitian sangat diperlukan analisis data yang berguna untuk memberikan jawaban terhadap permasalahan yang diteliti. Teknik analisis data dalam penelitian ini mengacu model interaktif oleh Miles \& Huberman (1994, p. 12) terdiri atas tiga alur yaitu: reduksi data, penyajian data, dan penarikan kesimpulan/verifikasi. 


\section{Hasil Penelitian dan Pembahasan}

Gambaran tentang SDN 006 dan SDN 008 Kecamatan Kuala Kampar Kabupaten Pelalawan

Kecamatan Kuala Kampar terletak lebih kurang $240 \mathrm{KM}$ dari pusat ibukota provinsi Riau dan lebih kurang $180 \mathrm{KM}$ dari pusat ibukota Kabupaten Pelalawan. Batas utara Kecamatan Kuala Kampar adalah Kecamatan Rangsang dan Kecamatan Sungai Apit Kabupaten Siak. Sebelah selatan adalah Kecamatan Pulau Burung Kabupaten Indragiri Hilir. Sebalah barat adalah Kecamatan Kundur Kabupaten Karimun Provinsi Kepulauan Riau. Sedangkan batas timur adalah Kecamatan Teluk Meranti dan Kecamatan Sungai Apit Kabupaten Siak.

Kecamatan Kuala Kampar, lebih dikenal dengan kawasan Kampar Hilir, ibu kotanya terletak di Kelurahan Teluk Dalam berlokasi di tepi Sungai Kampar, di Kecamatan Kuala Kampar terdiri atas 9 desa dan 1 kelurahan yaitu Teluk Dalam, Tanjung Sum, Sungai Solok, Sungai Upih, Teluk Sokoi, Serapung, Teluk Beringin, Sungai Emas, dan Teluk Bakau. Tingkat kepadatan penduduk Kecamatan Kuala Kampar adalah 18 Jiwa/KM persegi. Dengan jumlah penduduk 17.726 jiwa dan luas wilayah 1.000.39 KM Persegi. Potensi yang menonjol di Kecamatan Kuala Kampar adalah pertanian, perkebunan, peternakan dan perikanan.

Dimensi Kompetensi Manajerial Kepala SD Negeri 006 dan SD Negeri 008 Kecamatan Kuala Kampar

\section{Perencanaan}

Perencanaan sekolah yang dilakukan di SD Negeri 006 dan SD Negeri 008 Kecamatan Kuala Kampar dilaksanakan melalui penyusunan program perencanaan sekolah yang dilakukan setiap awal tahun dan menyampaikan setiap item-item program yang akan dilaksanakan kepada seluruh guru, staf dan karyawan di sekolah, karena guru, staf dan karyawan merupakan mitra atau rekan kerja di sekolah. Namun dalam pelaksanaan pada setiap ta- hunnya, kepala sekolah tidak pernah melibatkan para guru, staf dan karyawan serta tidak pernah melakukan musyawarah dalam penyusunan program perencanaan di sekolah.

Menurut Danim \& Suparno (2009, pp. 8-12), kepala sekolah bersama timnya harus berfikir untuk menentukan sasaransasaran kegiatan yang akan dilakukan di masa yang akan datang untuk mencapai tujuan. Dalam perencanaan mengandung unsur-unsur: (1) sejumlah kegiatan yang ditetapkan sebelumnya, (2) adanya proses, (3) hasil yang ingin di capai dan (4) menyangkut masa depan dalam waktu tertentu.

\section{Pengorganisasian}

Pengorganisasian sekolah dilakukan dalam rangka mengembangkan sekolah sesuai dengan kebutuhan yaitu melengkapi segala kebutuhan yang diperlukan oleh guru dalam proses belajar mengajar di sekolah agar siswa tertarik dalam proses pembelajaran yang diberikan oleh guru di kelas. Tetapi dalam pelaksanaanya, belum ada pengembangan yang dilakukan oleh kepala sekolah dalam rangka mengembangkan sekolah sesuai dengan kebutuhan di sekolah. Hal ini tidak sesuai dengan konsep pengorganisasian menurut Danim \& Suparno (2009, pp. 8-12) yang menyebutkan bahwa suatu proses pengaturan dan pengalokasian kerja, wewenang, dan sumberdaya dikalangan anggota sehingga sekolah dapat mencapai tujuan organisasi secara efektif dan efesien.

Pemberdayaan Sumber Daya Sekolah dan Sumber Daya Manusia.

Dalam rangka pemberdayaan serta meningkatkan sumberdaya sekolah dan sumber daya manusia di SD Negeri 006 dan SD Negeri 008 Kecamatan Kuala kampar adalah menjaga dan merawat semua aset yang ada di sekolah serta mengirimkan guru untuk mengikuti pelatihan, baik melalui MGMP maupun pelatihan yang dilaksanakan oleh pemerintah daerah, Provinsi maupun pemerintah pusat. Namun dalam pelaksanaanya baik dalam pember- 
dayaan sumber daya sekolah maupun sumber daya manusia di sekolah belum ada cara atau langkah-langkah yang dilakukan sekolah serta tidak pernah melibatkan guru dalam membuat keputusan. Dewi (2013, p. 1) menyatakan bahwa manajer dituntut untuk dapat mengelola bebe-rapa sumber daya termasuk manusia, sedangkan lainlain seperti keuangan, fasilitas, pengetahuan, informasi, waktu, dan lain-lain. Dengan memiliki kompetensi sebagai seorang manajer akan lebih mudah dalam mencapi tujuan yang telah ditetapkan."

\section{Pengelolaan}

Dalam rangka mengelola perubahan dan pengembangan sekolah menuju pembelajaran efektif di SD Negeri 006 dan SD Negeri 008 Kecamatan Kuala kampar yaitu kepala sekolah melibatkan guru-guru dalam proses pengembangan sekolah dengan cara melakukan percontohan terhadap sekolah-sekolah yang lebih maju. Tetapi dalam pelaksanaanya belum adanya pengelolaan perubahan sekolah menuju pembelajaran yang efektif.

Mintzberg (Toha, 2012, pp. 12-17) mengemukakan bahwa peranan utama seorang manajer terbagi dalam 3 peranan uta-ma. Ketiga peranan tersebut adalah sebagai berikut. Pertama, peranan hubugan antarpribadi (Interpersonal Role). Aktivitas yang sering digunakan dalam peranan ini antara lain kegiatan-kegiatan seremonial sehubungan dengan jabatan yang melekat pada manajer. Karena manajer mempunyai jabatan yang tinggi, maka manajer tersebut harus selalu mengadakan kontak pada pihak-pihak luar. Kedua, peranan yang berhubungan dengan informasi (Informational Role). Hubungan-hubungan keluar membawa padanya mendapatkan informasi yang spesial dari lingkungan luarnya, dan kegiatan-kegiatan kepemimpinannya membuat manajer sebagai pusat informasi bagi organisasinya. Ketiga, peranan pembuat keputusan (Decisional Role). Peranan ini membuat seorang manajer harus terlibat dalam suatu proses pembuatan strategi di dalam organisasi yang dipimpinnya. Proses pembuatan strategi ini secara sederha- na dinamakan sebagai suatu proses yang menjadikan keputusan-keputusan organisasi dibuat secara signifikan dan berhubungan.

\section{Budaya dan Iklim Sekolah}

Kepala sekolah menerapkan budaya melayu kepada guru dan siswa dengan cara saling mengucap salam. Selanjutnya dalam membentuk iklim sekolah efektif, kepala sekolah menciptakan lingkungan sekolah yang nyaman dan enak dipandang. Sedangkan dalam pelaksanaanya di SD Negeri 006 dan SD Negeri 008 Kecamatan Kuala kampar belum ada usaha yang dilakukan untuk menciptakan budaya yang kondusif dan menciptakan iklim sekolah yang kondusif bagi pembelajaran peserta didik.

Zahid \& Gihar (2012, p. 42) mengemukakan bahwa posisi kepala sekolah di dalam sebuah lembaga sekolah yaitu: "the principal holds a very important position in the entire system of education and he is the principal means for the implementation of educational programmers" Seorang kepala sekolah memegang posisi yang sangat penting dalam seluruh sistem pendidikan dan kepala sekolah merupakan pelaksana program pendidikan yang disepakati bersama. Jadi, posisi kepala sekolah merupakan pelaksana program-program yang ada di sistem pendidikan. Kepala sekolah dalam posisi yang sangat penting untuk mencapai tujuan-tujuan yang ditetapkan.

\section{Pemberdayaan Guru dan Staf}

Dalam pelaksanaanya belum pernah dilibatkan sesuai dengan kerja yang sudah dibebankan, melakukan trobosan-trobosan serta membekali guru-guru sesuai dengan perkembangan ilmu dan teknologi. Sedangkan dalam pemberdayaan staf belum terlihat hasil signifikan yang dilakukan oleh kepala sekolah dalam pelaksanaan kinerja di sekolah. Yukl (2009, p. 34) menyampaikan bahwa kewajiban dan tanggung jawab kepla sekolah dalam posisi sebagai manajerial adalah: (1) supervisi, (2) merencana dan mengorganisasi, (3) pembuatan keputusan, (4) memantau indikator, 
(5) pengendalian, (6) memberi penjelasan,

(7) mengkoordinasi, (8) konsultasi, (9) mengadministrasikan."

\section{Sarana dan Prasarana}

Mengelola sarana dan prasarana sekolah dalam rangka pendayagunaan secara optimal di SD Negeri 006 dan SD Negeri 008 Kecamatan Kuala kampar dengan cara menjaga serta merawat sarana dan prasarana di sekolah dengan baik, sehingga dapat dimanfaatkan oleh guru dan siswa. Sedangkan dalam pelaksanaanya tidak pernah dilakukan pengelolaan sarana dan prasarana di sekolah. Danim \& Suparno (2009, p. 4) mengatakan, "Kepala sekolah ditutut mampu berperan sebagai seorang pemimpin profesional. Ciri-ciri kepala sekolah profesional adalah menguasai secara baik pekerjaannya melebihi rata-rata personalia lain disekolah, dan memiliki komitmen moral yang tinggi atas pekerjaan sesuai dengan kode etik profesinya."

Hubungan Kerja sama Sekolah dengan Masyarakat

Mengelola hubungan sekolah dan masyarakat dalam rangka mencari dukungan, ide, sumber belajar dan pembiayaan di SD Negeri 006 dan SD Negeri 008 Kecamatan Kuala kampar yaitu dengan mencari ide-ide atau bermusyawarah bersama komite dan wali murid dalam memecahkan setiap masalah tentang belajar siswa, agar semua sumber belajar di sekolah terpenuhi. Sedangkan dalam pelaksanaannya belum ada hubungan komunikasi dan melakukan musyawarah dengan pihak masyarakat dalam rangka pemecahan setiap masalah yang timbul di lingkungan sekolah karena kepala sekolah masih berkerja sendiri dan setiap masalah yang timbul di sekolah tidak pernah melibatkan masyarakat di sekitarnya. Sementara dalam pembiayaan sekolah tidak ada donator luar maupun tambahan dari orang tua siswa dalam pembiayaan di sekolah. Dewi (2013, p. 1) menyatakan bahwa manajer dituntut untuk dapat mengelola beberapa sumber daya termasuk manusia, sedangkan lainlain seperti keuangan, fasilitas, pengetahu- an, informasi, waktu, dan lain-lain." Dengan memiliki kompetensi sebagai seorang manajer akan lebih mudah dalam mencapi tujuan yang telah ditetapkan.

\section{Kesiswaan}

Mengelola peserta didik dalam rangka peneriman peserta didik baru, penempatan, dan pengembangan kapasitas peserta didik di SD Negeri 006 dan SD Negeri 008 Kecamatan Kuala kampar, dalam penerimaan peserta didik yaitu mengadakan rapat dengan guru-guru, staf dan karyawan guna membetuk panitia PSB. Sementara dalam pelaksanaan penerimaan siswa baru belum ada pengelolaan yang jelas dilakukan karena guru hanya menerima pendaftaran peserta didik baru tanpa ada memegang program dari sekolah. Misalnya berapa siswa yang harus diterima, batas minimal berapa yang di terima, bagaimana penempatan siswa, apakah berdasarkan nilai atau di susun secara heterogen serta tidak ada penjelasan tentang penempatan peserta didik baru semua ini hanya dilakukan dari inisiatif para guru di sekolah.

\section{Kurikulum}

Mengelola pengembangan kurikulum dan kegiatan pembelajaran sesuai dengan arah dan tujuan sekolah di SD Negeri 006 dan SD Negeri 008 Kecamatan Kuala kampar dengan melaksanakan metode-metode kurikulum dari hasil pelatihan, metode tersebut dikembangkan sesuai dengan kondisi dan situasi sekolah. Sementara pada pelaksanaannya pengelolaan pengembangan kurikulum yang dilakukan tidak sesuai dengan arah dan tujuan sekolah serta tidak pernah menyampaikan setiap program tentang kurikulum, hal ini dilakukan hanya inisiatif para guru berdasarkan pengalaman.

Hal ini tidak sesuai dengan konsep pengembangan kurikulum adalah kegiatan mengoperasionalkan visi, misi, tujuan, dan target sekolah dengan mengacu pada kurikulum nasional dan lokal yang berlaku sesuai dengan situasi dan kondisi sekolah yang dijabarkan dalam program tahunan dan program semesteran berdasarkan ka- 
lender pendidikan agar proses pembelajaran berjalan dengan baik dan mengacu pada pencapaian tujuan belajar siswa.

\section{Keuangan}

Mengelola keuangan sekolah sesuai dengan prinsip pengelolaan yang akuntabel, transparan, dan efesien di SD Negeri 006 dan SD Negeri 008 Kecamatan Kuala kampar yaitu setiap dana bos dan bosda yang peroleh dari pemerintah, dana tersebut digunakan pada subbagian sesuai dengan petunjuk dari pemerintah, tidak melenceng dari ketentuan yang berlaku, pengunaan dana tersebut diketahui oleh guru dan karyawan di sekolah. Sedangkan dalam pelaksanaanya, setiap guru-guru tidak pernah diikutsertakan dalam membuat program perencanaan keuangan, tidak memberikan informasi baik secara tertulis maupun lisan, guru tidak mengetahui tentang pemasukan dan pengeluaran dana, guru tidak mengetahui apakah pengelolaan keuangan tersebut sudah sesuai dengan prinsip pengelolaan yang ankuntabel, transparan dan efesien di sekolah.

Adegbemile (2011, p. 18) menyatakan, "The financial management skills principals needed for effective schools' administration among others include: principal preparing budget jointly with the management staff, sourcing for funds, keeping accurate financial information, giving true and fair financial position of the school" Keterampilan manajemen keuangan kepala sekolah yang diperlukan untuk administrasi sekolah yang efektif antara lain meliputi: pokok menyusun anggaran bersama-sama dengan staf manajemen, sumber dana, menjaga informasi keuangan yang akurat, memberikan posisi keuangan yang benar dan adil di sekolah.

\section{Ketatausahaan}

Mengelola ketatausahaan sekolah dalam mendukung pencapaian tujuan sekolah di SD Negeri 006 dan SD Negeri 008 Kecamatan Kuala kampar yaitu dengan memberikan pelatihan-pelatihan yang menyangkut tugas ketatausahaan, agar semua pekerjaan yang dilakukan dapat disele- saikan tepat pada waktunya. Namun dalam pelaksanaanya belum ada pelatihanpelatihan yang diberikan serta seluruh tugas hanya dilakukan sesuai perintah tanpa tujuan.

Hal ini tidak sesuai dengan konsep ketatausahaan yaitu bagian dari unit pelaksana teknis penyelenggaraan bidang administrasi dan informasi data pendidikan yang perlu dikelola oleh kepala sekolah dengan sebaik-baiknya sesuai ketentuan yang berlaku. Menurut Dewi (2013, pp. 12), manajer adalah orang yang berada dalam suatu organisasi, dimana harus dapat menjalankan peranannya karena sebagai bagian dari orang yang bertanggung jawab pada banyak bawahan. Artinya, ketika seseorang menjabat sebagai seorang manajer maka dia harus mampu menjadi sandaran bawahannya dalam kondisi dan situasi apapun.

\section{Unit Layanan Khusus}

Mengelola unit layanan khusus sekolah dalam mendukung kegiatan pembelajaran dan kegiatan peserta didik di SD Negeri 006 dan SD Negeri 008 Kecamatan Kuala kampar masih belum ada, seperti bimbingan konseling dilaksanakan melalui wali kelas dan bagian kesiswaan, Sedangkan dalam pelaksanaanya dilakukan apa adanya. Hal ini dari faktor sarana dan prasarana yang tidak memadai seperti UKS dan ruang bimbinag konseling yang tidak disediakan. Menurut Armstrong (2009, p. 15), Manajers are there to get results by ensuring that their function, unit or department operates effectively. They manage people and their other resources finance, facilities, knowledge, information, time and themselves." Manajer ada untuk mendapatkan hasil dengan memastikan bahwa fungsi unit atau departemen beroperasi secara efektif. Mereka mengelola sumber daya, fasilitas, pengetahuan, informasi, waktu dan diri mereka sendiri.

\section{Pengelolaan Sistem Informasi Sekolah}

Mengelola sistem informasi sekolah dalam mendukung penyusunan program dan pengambilan keputusan di SD Negeri 
006 dan SD Negeri 008 Kecamatan Kuala kampar yaitu biasanya melakukan dengan cara kegiatan-kegiatan perlombaan yang diikuti di tingkat kecamatan dan kabupaten. Namun dalam pelaksanaannnya tidak pernah Tidak ada pengelolaan sistem informasi yang jelas oleh kepala sekolah untuk mendukung program-program sekolah.

Kendala Implementasi Dimensi Kompetensi manajerial Kepala Sekolah SD Negeri 006 dan SD Negeri 008 Kecamatan Kuala Kampar. (1) kurangnya sarana dan prasarana untuk menunjang proses belajar mengajar disekolah menjadi kendala dalam menjalankan tugasnya; (2) jarak antara sekolah dengan pusat kota yang jauh menjadi penghambat program-program sekolah; (3) kurangnya motivasi kepala sekolah. Karena selama ini kepala sekolah btelah bertugas sekitar 25 tahun lebih sehingga terkesan aman dengan posisinya; (4) kurangnya perhatian dan kerja sama dengan masyarakat sekitar berkaitan dengan perkembangan sekolah; (5) Kepala sekolah tidak memiliki standar kompetensi kepala sekolah sesuai dengan peraturan pemerintah. (6) kurangnya koordinasi dan kerja sama kepala sekolah dengan bawahan dan sehingga kepala sekolah terkesan bekerja sendiri tanpa ada musyawarah dengan guru, staf dan karyawan di sekolah.

Busher (2006, p. 141) menjelaskan pentingnya iklim kerja yang kondusif dalam sebuah lembaga untuk mencapai tujuan bersama. "An important element in middle leaders' success in running departments is their ability to help colleagues develop their capacities as teachers and leaders. To do this, leaders need to understand colleagues' personal and work-related needs and interests and help them to understand the culture of their particular school, to engage with the subculture of the department and to appreciate the complexity of students' small cultures."

Sebuah elemen penting dalam keberhasilan pemimpin tengah dalam menjalankan departemen adalah kemampuan mereka untuk membantu rekan-rekan mengembangkan kapasitas mereka sebagai guru dan pemimpin. para pemimpin perlu memahami kebutuhan dan kepentingan pribadi dan pekerjaan yang berhubungan dan membantu mereka untuk memahami budaya sekolah.

Masa Tugas Kepala Sekolah SD Negeri 006 dan SD Negeri 008 Kecamatan Kuala Kampar

Kepala sekolah SD Negeri 006 dan SD Negeri 008 Kecamatan Kuala kampar sudah 25 tahun atau 6 periode masa bertugas disekolah SD Negeri 006 dan SD Negeri 008 Kecamatan Kuala kampar. Alasan kepala sekolah tidak pernah dimutasi adalah kerena kepala sekolah SD Negeri 006 dan SD Negeri 008 Kecamatan Kuala kampar dinaggap senagai salah satu tokoh masyarakat di desa tanjung sum, sehingga ketika akan ada pergantain kepala sekolah maka masyarakat mengajukan permohonan kepada UPTD Pendidikan, agar kepala sekolah yang sudah ada tidak diganti. Sedangkan hasil wawancara terhadap pengawas dan Kepala UTPD Pendidikan Kecamatan Kuala Kampar menyebutkan bahwa memang kepala sekolah SD Negeri 006 dan SD Negeri 008 Kecamatan Kuala kampar sudah lama bertugas di sekolah tersebut. Tidak pernah diganti dikarenakan permintaan dari tokoh masyarakat di lingkungan SD Negeri 006 dan SD Negeri 008 Kecamatan Kuala kampar. selain itu dikhawatirkan kepala sekolah yang baru tidak mampu beradaptasi dengan kondisi lingkungan masyarakat disana yang secara geografis jauh dari perkotaan.

Hal ini bertentangan dengan Permendiknas No. 28 Tahun 2010, Guru dapat diberikan tugas tambahan sebagai kepala sekolah/madrasah untuk memimpin dan mengelola sekolah/madrasah. Masa tugas ataupun masa jabatan Kepala sekolah/ madrasah diberi 1 (satu) kali masa tugas selama 4 (empat) tahun. Masa tugas kepala sekolah/madrasah dapat diperpanjang untuk 1 (satu) kali masa tugas apabila memiliki prestasi kerja minimal baik berdasarkan penilaian kinerja. Guru yang melaksanakan tugas tambahan sebagai kepala sekolah/madrasah 2 (dua) kali masa tugas berturut-turut, dapat ditugaskan kembali menjadi kepala sekolah/madrasah di sekolah/madrasah lain yang memiliki nilai 
akreditasi lebih rendah dari sekolah/madrasah sebelumnya, apabila telah melewati tenggang waktu sekurang-kurangnya 1 (satu) kali masa tugas; atau memiliki prestasi yang istimewa. Yukl (2009, p. 3) menyatakan bahwa sebagian besar dari definisi kepemimpinan mencerminkan kepemimpinan berkaitan dengan proses yang disengaja dari seseorang untuk menekankan pengaruhnya yang kuat terhadap orang lain yang membimbing, membuat struktur, memfasilitasi aktivitas dan hubungan di dalam kelompok atau organisasi."

Keterbatasan Penelitian

Penelitian dilakukan dengan metode kualitatif dan menggunakan data primer yang diperoleh melalui wawancara, observasi dan dokumentasi. Keterbatasan yang dihadapi pada penelitian ini adalah tempat penelitian yang secara geografis berada jauh dari perkotaan dan transportasi perjalanan yang sulit untuk menuju ketempat penelitian. Selain itu keterbatasan lain yang dihadapi peneliti dalam pengambilan data adalah memberikan pemahaman tentang maksud dari pertanyaan yang diajukan peneliti, sebagian informan kurang begitu memahami maksud dari pertanyaan yang diajukan, sehingga peneliti perlu menjelaskan kembali maksud dari pertanyaan tersebut.

\section{Simpulan dan Saran}

Berdasarkan hasil penelitian yang dilakukan melalui wawancara dan dokumentasi, peneliti menyimpulkan sebagai berikut. Pertama, Implementasi dimensi kompetensi manajerial kepala sekolah di SD Negeri 006 Tanjung Sum dan SD Negeri 008 Sungai Solok belum terlaksana dengan baik sesuai dengan indikator dimensi kompetensi manajerial yang meliputi: (1) perencanaan; (2) pengorganisasian sekolah; (3) pemberdayaan sumber daya sekolah; (4) pengelolaan perubahan dan pengembangan sekolah; (5) menciptakan iklim dan budaya yang kondusif; (6) pengelolaan guru dan staf (7) pengelolaan sarana dan prasarana; (8) hubungan sekolah dan masyarakat; (9) pengelolaan peserta didik; (10) pengembangan kurikulum; (11) pengelolaan Keuangan; (12) pengelolaan ketatausahaan; (13) unit layanan khusus; (14) sistem informasi sekolah; (15) pemanfaatan kemajuan teknologi; (16) monitoring, evaluasi dan pelaporan. Kedua, Faktor-faktor yang menjadi kendala dalam implementasi kompetensi manajerial di SD Negeri 006 Tanjung Sum dan SD Negeri 008 Sungai Solok adalah sebagai berikut: (a) jarak antara sekolah dengan kota yang jauh menjadi penghambat program-program sekolah; (b) kurangnya sarana dan prasarana untuk menunjang proses belajar mengajar disekolah; (c) Kepala sekolah telah bertugas selama lebih 25 tahun tanpa adanya periodisasi jabatan, sehingga motivasi kepala sekolah menjadi rendah; (d) Kepala sekolah belum memiliki dimensi kompetensi sebagai kepala sekolah yang wajib dimiliki sesuai dengan Peraturan Menteri Pendidikan Nasional; (e) kurangnya koordinasi dan kerja sama antara kepala sekolah dengan bawahan sehingga kepala sekolah terkesan bekerja sendiri tanpa melibatkan guru dan tenaga kependidikan di sekolah. Ketiga, faktor-faktor yang mempengaruhi periodisasi jabatan kepala sekolah di SD Negeri 006 Tanjung Sum dan SD Negeri 008 Sungai Solok tidak berjalan: (a) permohonan tokoh masyarakat di lingkungan sekolah kepada Kepala UPTD Kecamatan Kuala kampar karena kepala sekolah tersebut dianggap sebagai salah satu tokoh yang dibutuhkan oleh masyarakat; (b) ada kekhawatiran kepala sekolah baru tidak dapat beradaptasi dengan kondisi lingkungan masyarakat disana. (c) Ada Kehawatiran dari pihak UPTD timbulnya dampak sosial di masyarakat apabila kepala sekolah tetap diganti. Mengingat selama ini kepala sekolah tersebut telah dianggap sebagai tokoh penting oleh masyarakat desa.

Berdasarkan hasil penelitian pelaksanaan kompetensi manajerial di SD Negeri 006 Tanjung Sum dan SD Negeri 008 Sungai Solok kabupaten Kampar maka dapat disarankan: Pertama, bagi Dinas Pendidikan Kabupaten Pelalawan. (a) Agar lebih meningkatkan sosialisasi dan pelatihan 
khususnya kepada kepala sekolah yang belum memiliki standar dimensi kompetesi kepala sekolah; (b) lebih meningkatkan kepengawasan dan perhatian melalui supervisor dalam pengembangan kompetensi manajerial bagi kepala sekolah; (c) hendaknya melakukan sosialisasi langsung kepada masyarakat berkaitan dengan peraturan periodisasi kepala sekolah; (d) ketegasan dan konsistensi dinas pendidikan sangat diperlukan untuk menerapkan secara utuh aturan periodisasi jabatan kepala sekolah.

Kedua, bagi Kepala Sekolah:(a) Kepala sekolah diharapkan dapat menjalin kerja sama dengan bawahan sehingga kompetensi manajerial dapat terlaksana dengan baik di sekolah; (b) Guru dapat melakukan kerja sama yang baik dengan kepala sekolah dalam proses pelelaksanaan program sekolah; (c) hendaknya kepala sekolah memberikan teladan kepada guru, tenaga kependidikan dan warga sekolah.

\section{Daftar Pustaka}

Adegbemile, O. (2011). Principals' competency needs for effective schools' administration in Nigeria, 2(4), 15-24. Retrieved from http://www.iiste.org/Journals/index .php/JEP/article/view/436

Armstrong, M. (2009). Armstrong's handbook of management and leadership a guide to managing for results. London and Philadelphia: Kogan Page.

Bennis, W. (2009). On becoming leader: The leadership classic. New York: Basic Books.

Busher, H. (2006). Understanding educational leadership people, power and culture. New York: Open University Press.

Danim, S., \& Suparno. (2009). Manajemen dan kepemimpinan transformasional kepalasekolahan. Jakarta: Rineka Cipta.

Depdiknas. Peraturan menteri pendidikan nasional nomor 13 tahun 2007 tentang standar kepala sekolah/madrasah (2007).

Depdiknas. Peraturan menteri pendidikan nasional no 28 tahun 2010 tentang penugasan guru sebagai kepala sekolah/madrasah (2010)

Dewi, I. C. (2013). Teori kepemimpinan managerial (managership). Jakarta: Prestasi Pustakaraya.

Kompri. (2015). Manajemen Sekolah (orientasi kemandirian kepala sekolah). Yogyakarta: Pustaka Pelajar.

Miles, M. B., \& Huberman, A. M. (1994). An expanded sourcebook qualitative data analysis. (California, Ed.) (2nd ed.). Sage Publication.

Ndidi, P., Obigeli, C., \& Peace, M. (2013). Managerial skill and enhancement strategis of scendary school principals. Journal Education and Practice, 4(26), 173. Retrieved from http://www.iiste.org/Journals/index .php/JEP/article/download/9871/10 079

Pidarta, M. (2011). Manajemen pendidikan Indonesia. Jakarta: Rineka cipta.

Robbins, S. P., \& Judge, T. A. (2013). Organizational behavior (15th ed.). London: Pearson Education Ltd.

Sergiovanni, T. J. (2006). The principalship a reflective practice perspective (5th ed.). Boston: Pearson.

Toha, M. (2012). Kepemimpinan manajemen. Jakarta: Rajawali Press.

Usman, H. (2013). Manajemen teori, praktik, riset pendidikan. Jakarta: Bumi Aksara.

Wahjosumidjo. (1999). Kepemimpinan kepala sekolah: tinjauan teoritik dan permaslahannya. Jakarta: Rajagrafindo Perkasa.

Wahyudi. (2012). Kepemimpinan kepala sekolah dalam organisasi pembelajaran. Bandung: Alfabeta.

Yukl, G. (2009). Kepemimpinan dalam organisasi. (terjemahan Budi Supriyanto). New Jersey: Prentice Hall, Inc.

Zahid, M., \& Gihar, S. (2012). Adjustment level of principals in realtion to gender and locality. Jurnal of Education and Practice, 3(11), 42-45. Retrieved from

http://www.iiste.org/Journals/index .php/JEP/article/view/2543 